\title{
Buying Predilection of Buyers towards Branded Mobile Phones Devices
}

\author{
Rambabu Lavuri, Durgaprasad Navulla, Maloth Naresh Naik
}

\begin{abstract}
Despite the rapidly growing competition in the present market situation, there is a necessity of realizing the significance of buyers purchasing behaviour and it is terribly applicable to analyse the drivers which is related to consumer predilection. This research investigates and analyses the predilection towards mobile phones. In this paper consider four factors which are impacting on buyers predilection namely media exposure, mobile predilection factors, mobile features and purchasing mode of the buyers. To achieve the study objective, the researcher has taken 227 sample sizes from the selected area of research by using the convenience method. A stratured survey was utilized to collect the data and analyzed through the use of Analysis of variance, pearson correlation and multiple regression analysis by the use of statistical package 23.0. From the results, media exposure variable statistical influenced on the buying predilection; mobile predilection factors brand name and price of mobiles have good strength of association with buyers predilection, mobile features Processor power, camera and style and design significant impact on buyers predilection towards branded mobile phones and most of the buyers purchasing their mobile handset through offline purchasing mode. It was clear that each variables of mobile predilection factors and mobile features among all acted as a motivational power that impact on buying predilection of buyers towards branded mobile phones.
\end{abstract}

Key words: Buying predilection, Camera, Media exposure, Mobile features, Online - Offline, Processor power, Style and Design.

\section{INTRODUCTION}

Mobile handset is a part of every one life, it is not for correspondence thought process yet in addition it come to be single aid similarity with perform day by method for ways of life easier. Everyone, irrespective of their socio economical profile accepted mobile phones as a crusial thing to daily lofe of every one. Mobilephone development innovation technology, which consistanly creating and invigorating as an outcome of buyers altering their tendencies and requirements ( Mokhlis, S. A.Yaakop, 2012). An issue is there by growing competation in mobile market segment by the launching new brand mobile phones with great features and technology, through this competition buyers will get a wide varieties of mobile handsets to select from the mobile segment and at the time disarray winning in the psyches of purchasers towrads specific handset ensembles with their

Revised Manuscript Received on November 11, 2019.

* Correspondence Author

Dr. Rambabu Lavuri, Faculty, School of Management, NIT Warangal, Telangana, India.

Dr.Durgaprasad Navulla, Faculty, School of Management, NIT Warangal, Telangana, India.

Dr. Maloth Naresh Naik, Asst. Professor, Depart. Of Management, Osmania University, Telangana, India.
necessisties.Cell phone industry everywhere throughout the globe is presently going through a fierce business condition because of increasing challenge just as the constant changes in the predilection, inclinations and prerequisites of the buyers. Because of this, the business companies continually take part in advancement and separation to meet and fulfill buyer inclinations. In any case, the purchaser conduct writing has not many investigations that reveal the hidden intentions and selections of buyers during cell phone buy process. At the initial phase, cell phones were utilized for maintaing better communication exclusively. Due to great technology developments, progressions along with combination of highlights of different business, item usefulness of has vanished past creative mind. The business is energetic and market knows about crisp modelson seven days by week premise. $3 \mathrm{G}$ and $4 \mathrm{G}$ accessibility innovation and smart mobile improvement have created an individuval advancedcollaboratorsmobile phones.

\section{Mobile Market share in India (2018-2019)}

Mobile sector is the quickest growing segment in the present scenario, this segment become very significant part of human life. Branded phones are very dynamic and buyers predilection will change on the based on new technology and high resolution camera, fast processors, user friendly, style and design are the major features influenced on buying predilection of buyers. As for indian mobile market share, chinese mobile brands reached 66 percent durin Q1 2019. Xiaomi smartphone (29\%), Samsung (23\%), Vivo (12\%) and oppo (7\%) are a leaders in during Q1 2019 of market share.Second greatest mobile phone market is the india, which incorporates cozy more prominent around 400 set stepped cell phone clients before the US then 33 measurement in regards to cell phones purchased inside Rs. 11,000 according to Rs. 18,000 cost extend, as piece is expanding at present however an order about appreciation is internal case since enormous net markdown then critical dispatches over as per need brief makers may advance exceptional quantities. The chinese versatile associations bear above 60 percent agony incorporating honor as per the crucial venture of the indian. Mobile phone sector have incalculable drivers, this concept of intermixing takes prime significance in the atitude of the clients. Usage enhancement scheme acepts a main conditionin compliance of undertsanding endorsers for mobile cellphones administrations and models. This moblie industry is a ever-changing sector, and mobile comapnies future engine with mmobile transmission in india probable to grow year on year and 5.4 million mobile phones anticipated sold in india by 2009. 4G introduction 
in india will be of assistance to expand market of mobile phone sector, with customers implementation a cellular phone to maintain information scaling appliaction that can be advanced with $4 \mathrm{G}$. With the presentation of $4 \mathrm{G}$ in India, the cell phone market is relied upon to see an expansion in the take-up, as customers would embrace a cell phone to help the information escalated applications that can be upheld on a $4 \mathrm{G}$ arrange. It is normal that the supplanting business sector will take off with a high number of purchasers hoping to exchange up to cell phones from conventional element telephones. There is an excessive quantity of the desire to absorb customer imitation of cell phone trade, besides traditional telephones, every day. This is a continuous improvement between the industry, yet cell phone business is likely to continue after bibcock along phone shipments between India and India.

\section{LITERATURE REVIEW}

Mesay Sata, Shnka (2013) invegates that effects of media exposures on consumers desire, awareness, conviction and post purchasing mode by examine the exposures vehicles like radio, the internet, newspapers and magazine. This research concluded that $\mathrm{N} \& \mathrm{M}$ had greater impact on pre -post purchase bahaviour and also on consumers five purchasing stages and followed by TV and internet helpful to generating desire and giving brief convection among of them. Satinder Kumar and Parveen (2016) investagte the attributes affecting on buyers purchase decision towards the buying of the Mobile Phones and the study result concluded that attributes like technical features, looks, image \& resource are the most considered buying predilection factors and entertainment plays a vital role on buyers buying decision. The instrictioin recommend the the strategies which might be received by the promoters to improve mindfulness among the purchasers. Sama, R. (2019) study that affecting of mobile phone factors on purchasing decision making of consumer. The study analyzed six factors like brand name, item durability, features, after sales services and influence of social group on them. Thes study conclud that price and mobile phone features are most motivational forces among all variables which influence on buyers purchase decision. Macro analysis and consumer research organization (2004) investigated that the factors like usage patterns and attitude of purhcasers trigger on their purchase behaviour and their awreness regarding new handsets. The result disclose that technology is the prior to buyers purchase, and great attentiveness towards new branded mobiles and lions share of the buyers perceive a mobile phones asthe innovation that offers comfort and build consumers life simpler. Chowdhary, M and Rahman, T (2013) viewed the attachement among socio economical factors consumers. Factors like charecterstics, perceived and inclination of brand, which are influence on purchasing choice over cellular phones and the youthful purchasers give exceptional emphasis to some specific predilection factors like price, durability. and study also revealed that samsung is contending with market pioneer, and other branded moblie like nokia, sony erricson and other brand mobiles acquire small bit of market. Aakanksha, P V Gopal and Anjali (2013) explores that present maraket era, medium screen mobile is very mainstream and only minority of the people purchase the large screen mobile in the mobile

market. The study concluded that slim handsets have to priority to the buyers in the mobile market. J Marumbwa (2013) investigated that brand image and brand predilection are positiely influence the buying behaviour of the buyers, and these increase in buyers satisfaction levels. Most of the students prefered brand of product while buying the mobile handset; technology and economic factors play avital role to give prefer brand and tey get profer informatioin sources like internet and reference group i.e. friends towards branded mobile phones (Rijal. 2013).

Sata (2013) the study explore that young buyers take option to selected mobile handsets on the bases of mobile phones appearence, brand, new features, pleasure ability and usability; demographical factors like gender (female); education profile (PG), occupational group (students) and geographical group (urban residents) assumes very important role in the consumers purchasing choice of all mobilr handsets, and singh (2012) investigates the buyers preference towards various branded mobile phone handsets and study concluded that mobile predilection factors like multimedia options, price consciousness, mobile features and looks and mobile brand image factors majorly influenced on the buyers purchase behaviour towards mobile phones. While buying a smart phone, factors like design of product, integration of hardware and mobile smartware are the main determinants to influence buyers purchase decision towards smart phone. The role of brand in moving inclinations in the purchaser purchasing conduct. The examination highlightsthe underlined significance of brands and the dualism among promoting and innovation of the mechanical items (Luca. 2008). Mobile phone attributes liek features, design, life of battery, quality of camera $\&$ vedio, good speed browing connection impact on buyers in selcting mobile phones, these factor helful to consumers to overcome their confusion with various branded mobile handsets (Sandeep Kumar, 2015). Mobile factors like size, physical appearence are persuding towards mobile phoes preferences (Salvendy and Ling H., 2007). For investigating this research papers, among the an assortment of drives, four paramenters have been considered in this researach study namely media exposure, mobile predilection factors, mobile phone features and mobile purchasing mode. Objective of the research to investigate the buying predilection of buyers with respect to branded mobile phones based on this four parameters, and this study used statistical techniques like annova, correlation and regression for investigates the reasons that trigger the buying predilection of new buyers.

\section{RESEARCH OBJECTIVES AND HYPOTHESIS}

The major research objectives are followed below

- To study influence of media exposure on buyers predilection towards Branded mobiles.

- To analyze the mobile predilection factors influencing on the buyers to getting mobile phones.

- To examine the mobile features on buyers predilection towards buying mobile phones.

- To study the impact of online and offline purchasing on buyers 
towards getting mobile phones.

Following hypotheses are framed on the bases of objectves of study. Figure 1 discloses that the association among the independent variables (media exposure, factors drives to purchasing, mobile features and purchasing mode of devices), and the dependent variable (clients purchasing behviour).
HO1: There is no significant influence of Media Exposure on buyers predilection towards branded mobiles.

HO2: There is no significant affect of mobile predilection factors on buyers purchasing Branded mobiles.

HO3: There is no significant impact of Mobile features on predilection of buyers towards buying Branded mobiles.

HO4: There is no mean difference among online and offline purchasing mode towards branded mobiles.

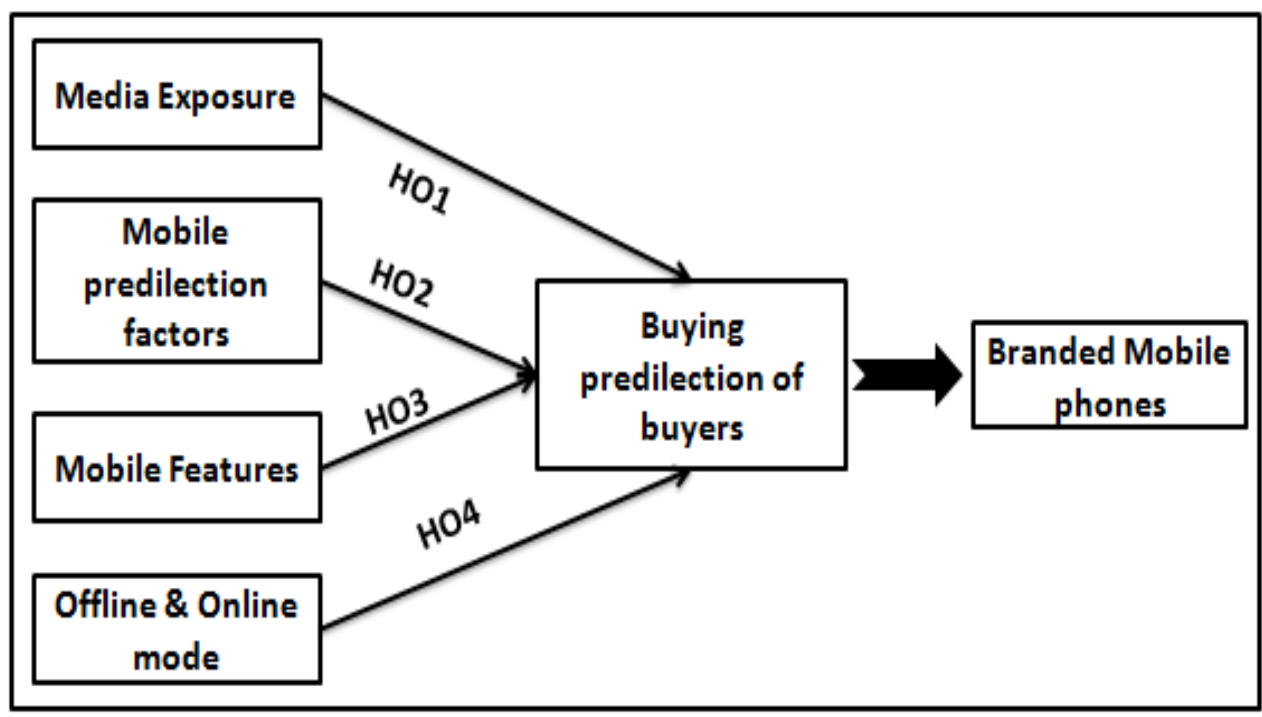

Figure 1 Hypotheses frame work

\section{METHODOLOGY:}

The present research adopts descriptive research design based on the buying predilection of buyers towards purchasing mobile devices from the Telangana state. We conducted the personal survey in south india including Hyderbad, Secunderabad, Warangal and Khammam from Telangana state in India. The research scope is limited to only four major towns/cities of Telangana stae. Keeping in view the objectives of the study, a questionnaire for the respondents was drafted. A Structure and closed-ended questionnaire was prepared and distributed among the respondents for capturing their responses pertaining to variable of the buying predilection of buyers purchasing towards branded mobiles devices. The questionnaire builds with two sections. First section has five questions, related to respondents socio economical factors, section two have 22 questions distributed between four variables. Five questions were framed to know the influence of the media exposure on buyers predilection about buying mobile phones; seven questions were included to assess the mobile features on buyers predilection towards mobile purchasing, eight questions were aimed investigates the affect of the predilection factors on buyers purchasing and two questions for examining the impact of purchasing mode on the respondents towards the branded mobile. Each questions consisted items for measuring the buying predilection of buyers regarding mobiles devices. The Researchers uses Likert scale (five point) for measuring their responses, the range of the scale from 1-very low influence to 5-very high influence. The research survey was under taken during the months of January to May 2019. Overall, 320 questionnaires were distributed to the sample respondents under the Convenience sampling method, we were able to receive feedback $71 \%$ (227) valid survey of the respondents from the four cities of Telangana state. Statistical tools like Std. Deviation, analysis of variance, correlation and multiple regressions used for analysis purpose with help of spss 23.0

Table 1 Sample and Response Rate

\begin{tabular}{|c|c|c|c|c|c|}
\hline S.no & Cities & State & Sample & $\begin{array}{c}\text { Usable } \\
\text { Returns }\end{array}$ & $\%$ \\
\hline 1 & Hyderabad & $\begin{array}{c}\text { Telangan } \\
\mathrm{a}\end{array}$ & 95 & 71 & 74 \\
\hline 2 & $\begin{array}{c}\text { Secunderaba } \\
\mathrm{d}\end{array}$ & $\begin{array}{c}\text { Telangan } \\
\mathrm{a} \\
\end{array}$ & 87 & 63 & 72 \\
\hline 3 & Warangal & $\begin{array}{c}\text { Telangan } \\
\mathrm{a}\end{array}$ & 78 & 52 & 66 \\
\hline 4 & Khammam & $\begin{array}{c}\text { Telangan } \\
\mathrm{a}\end{array}$ & 60 & 41 & 68 \\
\hline \multicolumn{3}{|c|}{ Total } & 320 & 227 & 71 \\
\hline
\end{tabular}

Source: Author's findings

\section{CONSEQUENCES AND DISCUSSIONS}

Table 2 Scale Construction $(\mathbf{n}=\mathbf{2 2 7})$

\begin{tabular}{|c|c|c|c|c|}
\hline Questionnaire & Items & Alpha & Mean & $\begin{array}{c}\text { Std. } \\
\text { Deviation }\end{array}$ \\
\hline
\end{tabular}




\begin{tabular}{|c|c|l|l|l|}
\hline Media Exposure & $\begin{array}{c}5 \\
\text { Items }\end{array}$ & 0.802 & 3.8714 & .30267 \\
\hline Mobile features & $\begin{array}{c}7 \\
\text { Items }\end{array}$ & 0.795 & 3.3935 & .52358 \\
\hline $\begin{array}{c}\text { Mobile } \\
\text { predilection } \\
\text { factors }\end{array}$ & $\begin{array}{c}8 \\
\text { Items }\end{array}$ & 0.772 & 3.9721 & .42385 \\
\hline $\begin{array}{c}\text { Purchasing } \\
\text { Mode }\end{array}$ & $\begin{array}{c}2 \\
\text { Items }\end{array}$ & 0.780 & 3.4743 & .56765 \\
\hline \multicolumn{4}{|c|}{ Source: Author's findings } \\
\hline
\end{tabular}

Cronbach alpha test measuring the internal consistency of all dimensions extarcted from $n$ exploretory analysisi. Table 2 explores that the cronbach alapha values The Cronbach's alpha values for Media Exposure, Consumer preference factors, Purchasing factors and consumer purchasing mode of mobiles are observed to be $0.802,0.795,0.772$ and 0.780 . The result shows good validity and reliability scores; revelaed that mean values and standerd deviation of the dependent variables. The mean values of Media Exposure, Consumer preference factors, Purchasing factors and consumer purchasing mode of mobiles are3.8714, 3.3935, 3.9721 and 3.4743 and their std. deviation values are .30267 , $.52358, .42385$ and .56765 .

6.2 Demographic profile of clients: The general demographic profile of the clients presented in the table 3 .

Table-3: Demographic profile of respondents

\begin{tabular}{|c|c|c|c|}
\hline \multirow{2}{*}{ Particulars } & \multirow{2}{*}{ Classification } & \multicolumn{2}{|c|}{$($ No. Respondents $=227)$} \\
\hline & & No of Responses & $\%$ \\
\hline \multirow{5}{*}{ Age } & $20-25$ & 49 & 21.6 \\
\hline & $26-30$ & 64 & 28.2 \\
\hline & $31-35$ & 62 & 27.3 \\
\hline & $36-40$ & 39 & 17.2 \\
\hline & 41 and above & 13 & 5.7 \\
\hline \multirow{3}{*}{ Gender } & Male & 156 & 68.7 \\
\hline & Female & 71 & 31.3 \\
\hline & Below Degree & 27 & 11.8 \\
\hline \multirow{3}{*}{ Education } & Degree & 119 & 52.5 \\
\hline & PG & 64 & 28.2 \\
\hline & Above PG & 17 & 7.5 \\
\hline \multirow{5}{*}{ Occupation } & Student & 25 & 11.0 \\
\hline & Govt Employee & 54 & 23.8 \\
\hline & Private Employee & 94 & 41.4 \\
\hline & Business & 30 & 13.2 \\
\hline & Self Employed & 24 & 10.6 \\
\hline \multirow{6}{*}{$\begin{array}{l}\text { Monthly } \\
\text { income (in } \\
\text { rupees) }\end{array}$} & Below 20,000 & 20 & 8.8 \\
\hline & $20,001-30,000$ & 113 & 49.8 \\
\hline & $30.001-40,000$ & 42 & 18.5 \\
\hline & $40,001-50,000$ & 28 & 12.3 \\
\hline & 50,001 and above & 24 & 10.6 \\
\hline & Total & 227 & 100.0 \\
\hline
\end{tabular}

Source: Author's findings

As per Table 3, descrptive analysis was done for the demographic profile of the clients, demographic characterstics like age, gender, educations, occupations and monthly income data collected from 227 respondents; $28 \%$ of majority clients belongs to 26-30years age group, $27 \%$ of them were $31-35$ years group. $21 \%$ belongs to the age group $20-25$ years, $17 \%$ and $5 \%$ of them were belonged $36-40$ years and 41 and above; $68.7 \%$ of them were male and remaining were female; Mostof the respondents were completed Graduation $(52 \%), 28 \%, 11 \%$ and $7 \%$ belongs to Post graduation, students and PG and above; $41 \%$ fo the respondnets were private employees, $23 \%$ of the respondents were belonged for Govt employees, $13 \%$ of them were belonged Business people; Income status of the respondents $49 \%$ of the theme were ranged from Rs. 20,001-30,000, followed by $18 \%, 12 \%, 10 \%$ and $8 \%$ with income level 30.001 - 40,000, 40,001-50,000, 50,001 and above and Below 20,000 respectively. 
Table 4 Respondents opinion on purchasing mobile phones

\begin{tabular}{|c|c|c|c|}
\hline \multirow{2}{*}{ Particulars } & \multirow{2}{*}{ Classification } & \multicolumn{2}{|c|}{$(n=227)$} \\
\hline & & No of Responses & $\%$ \\
\hline \multirow{5}{*}{$\begin{array}{c}\text { Frequency of } \\
\text { changing mobile } \\
\text { phone }\end{array}$} & Lees than 6 months & 21 & 9.3 \\
\hline & $6-12 \mathrm{~m}$ & 44 & 19.4 \\
\hline & 1-2 years & 117 & 51.6 \\
\hline & $2-3$ years & 34 & 14.9 \\
\hline & above 3 years & 11 & 4.8 \\
\hline \multirow{6}{*}{$\begin{array}{c}\text { Money spend on } \\
\text { purcahnging mobile } \\
\text { phones }\end{array}$} & Less than 5,000 & 12 & 5.3 \\
\hline & $50,001-10,000$ & 29 & 12.8 \\
\hline & $10,001-15,000$ & 43 & 18.9 \\
\hline & $15,001-20,000$ & 69 & 30.4 \\
\hline & $20,001-25,000$ & 42 & 18.5 \\
\hline & Above 25,001 & 32 & 14.1 \\
\hline \multirow{3}{*}{$\begin{array}{l}\text { Mode of purchasing } \\
\text { mobile phones }\end{array}$} & Online shopping & 75 & 33.1 \\
\hline & Offline shoping & 152 & 66.9 \\
\hline & Total & 227 & 100.0 \\
\hline
\end{tabular}

Source: Author's findings

Table-5: Brand of mobile phones $(\mathbf{n = 2 2 7})$

\begin{tabular}{cccc}
\hline \multicolumn{4}{c}{ Table-5: Brand of mobile phones $(\mathbf{n}=\mathbf{2 2 7})$} \\
\hline 1 & Mobile Brands & Frequency & \% \\
2 & Samsung & 39 & 17.2 \\
3 & Nokia & 12 & 5.3 \\
4 & Sony & 11 & 4.8 \\
5 & Htc & 12 & 5.3 \\
6 & Vivo & 23 & 10.2 \\
7 & Apple & 20 & 8.8 \\
8 & Lenovo & 27 & 11.9 \\
9 & Oppo & 26 & 11.4 \\
10 & Intex & 14 & 6.1 \\
11 & Redmi & 32 & 14.2 \\
\hline & MicroMax & 11 & 4.8 \\
\hline
\end{tabular}

Source: Author's findings

Disk 4 disclose that, most of clients are replaced their mobile phones within 1-2 year gap, $19.4 \%$ respondents changing their mobile within 6-12 months, $14 \%$ of them were $2-3$ years, $9 \%$ of them were less than 6 months and $4 \%$ for within 3 years and above; $30.4 \%$ respondents spent their money $15,001-20,000,18.9 \%$ of them were spent money $10,000-15,000,18.5 \%$ people spent money 20,000-25,000,
$14 \%$ people spent their money above $25,001,5 \%$ people spend money less than 5,000 on purchasing mobile phones; $66.9 \%$ of the respondents purchased their branded mobiles through Offline mode and $33.1 \%$ of them were purchased from Online mode; table 5 mentions that, respondents were solicited to make 
reference to the branded mobile phones, which are using presently. From the eleven branded mobile phones being studied and asked to respond the questions, $17.2 \%$ of Samsung, $14.2 \%$ of Redmi, $11.9 \%$ for Lenovo and $11.4 \%$ for Oppo.

6.3 Results of ANOVA: It is used for examine the difference among group means in thesample using F-distribution value.

HO1: There is no significant influence of Media Exposure on buyers predilection towards branded mobiles.

Table 6 Anova result

\begin{tabular}{|c|c|c|c|c|c|c|}
\hline \multicolumn{2}{|c|}{} & $\begin{array}{c}\text { Sum of } \\
\text { square }\end{array}$ & df & $\begin{array}{c}\text { Mean } \\
\text { square }\end{array}$ & f & Sig. \\
\hline \multirow{2}{*}{$\begin{array}{c}\text { Media } \\
\text { Exposure }\end{array}$} & $\begin{array}{c}\text { Between } \\
\text { Groups }\end{array}$ & 8.382 & 18 & .466 & $\begin{array}{c}2.33 \\
6\end{array}$ & $\begin{array}{c}.00 \\
2\end{array}$ \\
\cline { 2 - 7 } & $\begin{array}{c}\text { Githin } \\
\text { Groups }\end{array}$ & 41.456 & 208 & .199 & & \\
\cline { 2 - 7 } & Total & 49.838 & 226 & & & \\
\hline
\end{tabular}

Source: Author's findings

From the Table 6, it is explored that the statistical significant value of the media exposure $\mathrm{F}(18,208)=2.336$, $\mathrm{p}<0.05$, The result indicates that significant value is lesser than p-value; Hence, there is a strong evicence to sapport the alternative hypotheses and reject the null hypotheses and results reveals that media exposure have great significant influence on the predilection of the buyers and this exposure help them to creat awareness about new mobile handsets.

HO2: There is no significant affect of mobile predilection factors on buyers purchasing Branded mobiles.

Table 7 Anova result

\begin{tabular}{|c|c|c|c|c|c|c|}
\hline \multicolumn{2}{|c|}{} & $\begin{array}{c}\text { Sum of } \\
\text { square }\end{array}$ & df & $\begin{array}{c}\text { Mean } \\
\text { squar } \\
\text { e }\end{array}$ & f & Sig. \\
\hline \multirow{4}{*}{$\begin{array}{c}\text { Mobile } \\
\text { predilectio } \\
\text { n factors }\end{array}$} & $\begin{array}{c}\text { Between } \\
\text { Groups }\end{array}$ & 13.689 & 18 & .760 & $\begin{array}{c}1.73 \\
3\end{array}$ & $\begin{array}{c}.00 \\
1\end{array}$ \\
\cline { 2 - 7 } & Groups & 91.256 & $\begin{array}{c}20 \\
8\end{array}$ & .439 & & \\
\cline { 2 - 8 } & Total & $\begin{array}{c}104.94 \\
5\end{array}$ & $\begin{array}{c}22 \\
6\end{array}$ & & & \\
\hline
\end{tabular}

Source: Author's findings

Table 6 reveals that any significant impact of mobile predilection factors that drives to buying mode to buyers; The p-value of mobile factors at 18 degrees of the freedom is 0.001 , this value is less than P-value. The results show that there is strong proof for rejecting the null hypotheses and it is evident to accept the alternative hypotheses. It concluded that buyers were more influenced by the mobile predilection factors which are drives to them towards purchasing the mobile phones.

HO3: There is no significant impact of Mobile features on predilection of buyers towards buying Branded mobiles.
Table 7 Anova result

\begin{tabular}{|c|c|c|c|c|c|c|}
\hline \multicolumn{2}{|c|}{} & $\begin{array}{c}\text { Sum of } \\
\text { square }\end{array}$ & df & $\begin{array}{c}\text { Mean } \\
\text { square }\end{array}$ & $\mathrm{f}$ & $\begin{array}{c}\text { Sig } \\
.\end{array}$ \\
\hline \multirow{4}{*}{$\begin{array}{c}\text { Mobile } \\
\text { Features }\end{array}$} & $\begin{array}{c}\text { Between } \\
\text { groups }\end{array}$ & 7.100 & 18 & .394 & .844 & .007 \\
\cline { 2 - 7 } & $\begin{array}{c}\text { Within } \\
\text { Groups }\end{array}$ & 97.263 & 208 & .468 & & \\
\cline { 2 - 7 } & Total & 104.363 & 226 & & & \\
\hline
\end{tabular}

Source: Author's own

Table 7 indicates that any significant difference between the mobile features and the consumers buying preferences regarding mobile devices. The probabilistic value of Mobile features $F(18,208)=0.844, p<.05$; this revealed that mobile features have heigher influence on the clients predilection regarding purchasing, due to reject the null hypothesis.

HO4: There is no mean difference among online and offline purchasing mode towards branded mobiles.

Table 8 Anova result

\begin{tabular}{|c|c|c|c|c|c|c|}
\hline \multicolumn{2}{|c|}{} & $\begin{array}{c}\text { Sum of } \\
\text { square }\end{array}$ & df & $\begin{array}{c}\text { Mean } \\
\text { square }\end{array}$ & f & Sig. \\
\hline \multirow{2}{*}{$\begin{array}{c}\text { Online } \\
\text { Shopping }\end{array}$} & $\begin{array}{l}\text { Between } \\
\text { Group }\end{array}$ & 82.719 & 15 & 5.515 & 2.896 & .075 \\
\cline { 2 - 7 } & $\begin{array}{l}\text { Within } \\
\text { Groups }\end{array}$ & 321.281 & 211 & 1.415 & & \\
\cline { 2 - 7 } & Total & 404.000 & 226 & & & \\
\hline \multirow{2}{*}{$\begin{array}{c}\text { Offline } \\
\text { Shopping }\end{array}$} & $\begin{array}{l}\text { Between } \\
\text { Groups }\end{array}$ & 84.376 & 15 & 5.625 & 4.850 & .000 \\
\cline { 2 - 8 } & $\begin{array}{l}\text { Within } \\
\text { Groups }\end{array}$ & 263.287 & 211 & 1.160 & & \\
\cline { 2 - 8 } & Total & 347.663 & 226 & & & \\
\hline
\end{tabular}

Source: Author's own

Table 8 discloses that the case of Online Shopping $\mathrm{F}(15,211)=2.896, \mathrm{p}>0.05$, and its significance value is more than the $\mathrm{p}$ value, meaning thereby there is no significant influence of Online Shopping mode on consumer towards purchasing Mobile devices, whereas Offline Shopping mode is statistically significant, and its $F$ values $F(15,211)=2.896$, $\mathrm{p}<.05$ found to be statistically significant. Hence, offline shopping mode had great significant influence on clients decision towards purchasing of mobile phones.

6.4 Results of Pearson Correlation: Correlation tends to be used for finding a level of relationship or strength or association of two sets of a variable upon one another. 
Table 9 Correlation Constarctions

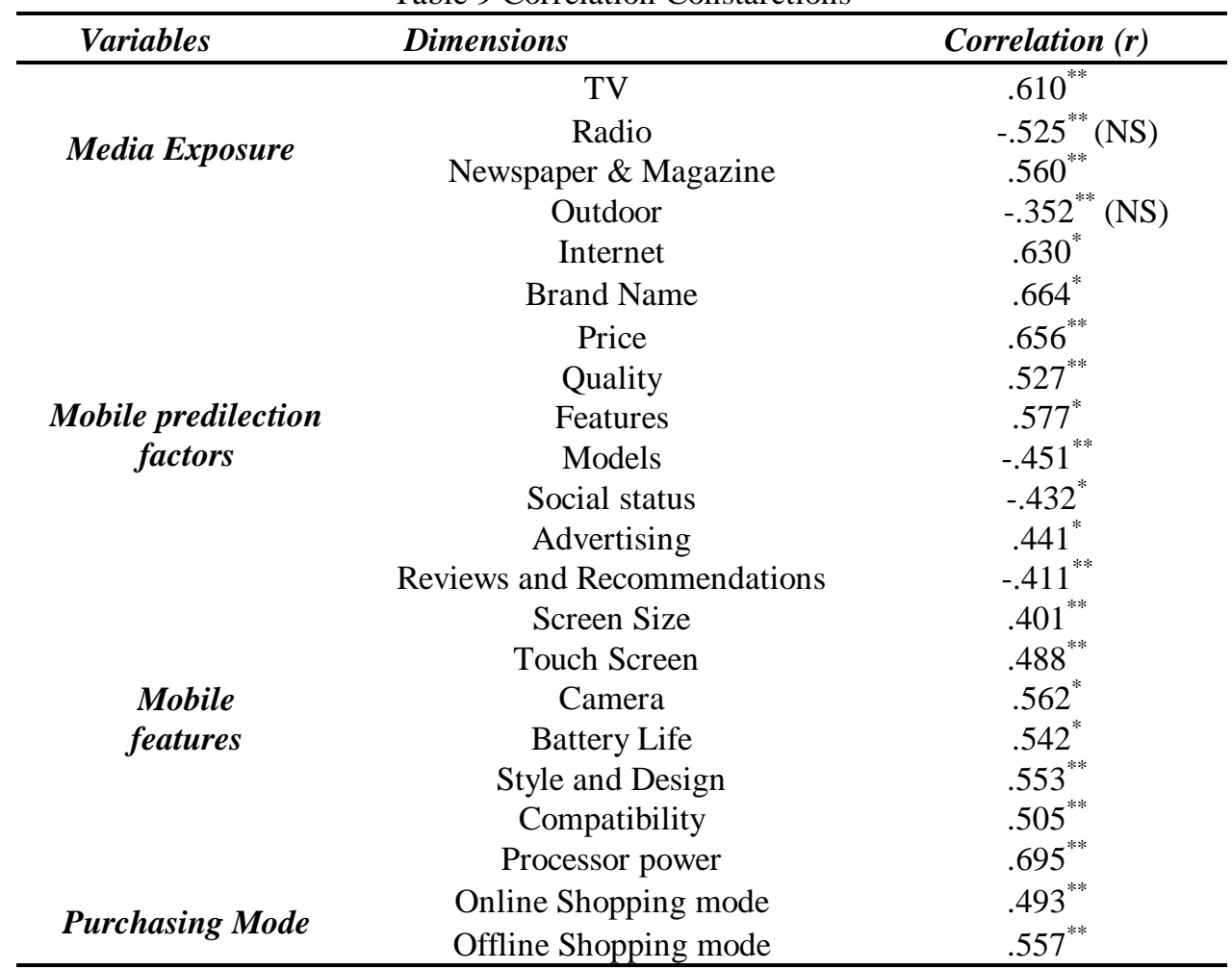

Table 9 explain the strenght of association between each of four independent variables like media exposure, mobile features, mobile factors that drives to purchasing and dependent variable consumer purchasing mobile phone; this pearson technique helpful to analyse degree of linear relationship among the variables. Media exposure variables like Internet $\left(\mathrm{r}=0.630^{* *}\right), \mathrm{TV}\left(\mathrm{r}=0.610^{* *}\right)$ and news paper $\&$ Magazine $\left(r=0.560^{* *}\right)$ have great significnt relationship with consumer purchasing mobile sets at the 0.01 level significant, where as radio and outdoor media exposure have negative relationship and statistical not significant with mobile purchasing; pearson correlation between mobile predeliction factors which drives buyers purchasing towards branded mobile sets have great strenght of association between them, each of variable like brand name $\left(r=0.664^{* *}\right)$, price $\left(r=0.656^{* *}\right)$ and features $\left(r=0.577^{* *}\right)$ have best relationship with purchasing behaviour of consumer towards mobile phones at the 0.05 and 0.01 level of significance and table also reveals that there is weak and negative relationship between variable like models $\left(\mathrm{r}=-0.451^{* *}\right)$, soccial status ( $\mathrm{r}$ $\left.=-0.432^{*}\right)$ and Reviews and Recommendations $\left(r=-0.411^{* *}\right)$ with consumer buying behaviour; each variable of mobile features like processsor power $\left(r=0.695^{* *}\right)$, compatibility ( $r$ $\left.=0.553^{* *}\right)$ and camera $\left(\mathrm{r}=0.562^{* *}\right)$ having good correlation with the consumer purchasing mobile phones at 0.01 and 0.05 level of significant; finally mobile purcasing mode variable like online mode $\left(r=0.493^{* * *}\right)$ and offline mode ( $r$ $=0.557^{* *}$ ) have good correlation with the consumer purchasing behaviour at the 0.01 level of significance.

\subsection{Results of Multiple Regression}

It is explaine the association between predictors and criterion variables in the research study and it helpful to identify the strength of effect that predictors will have on the criterion variable.

Table 10 Hypothese testing

\begin{tabular}{|c|c|c|c|c|c|c|}
\hline \multirow{2}{*}{ Hypotheses } & \multicolumn{2}{|c|}{ Relationship } & \multirow{2}{*}{$\begin{array}{l}\text { Std. } \\
\text { Beta }\end{array}$} & \multirow{2}{*}{$\begin{array}{l}\text { Std. } \\
\text { Error }\end{array}$} & \multirow{2}{*}{ t-value } & \multirow{2}{*}{ Result } \\
\hline & IV & DV & & & & \\
\hline $\mathrm{HO}_{1}$ & Media Exposure $\longrightarrow$ & $\begin{array}{l}\text { Consumer purchasing branded } \\
\text { mobiles }\end{array}$ & .200 & .050 & $3.070^{* *}$ & $R e j$ \\
\hline $\mathrm{HO}_{2}$ & $\begin{array}{l}\text { Mobile predilection } \\
\text { factors }\end{array}$ & $\begin{array}{l}\text { Consumer purchasing branded } \\
\text { mobiles }\end{array}$ & .526 & .069 & $9.284^{* *}$ & $R e j$ \\
\hline $\mathrm{HO}_{3}$ & Mobile features & $\begin{array}{l}\text { Consumer purchasing branded } \\
\text { mobiles }\end{array}$ & .221 & .060 & $3.404^{* *}$ & $R e j$ \\
\hline $\mathrm{HO}_{4}$ & Purchasing Mode $\longrightarrow$ & $\begin{array}{l}\text { Consumer purchasing branded } \\
\text { mobiles }\end{array}$ & .565 & .050 & $10.271^{* *}$ & $R e j$. \\
\hline
\end{tabular}

Note: $* * p<0.01 ; * * * p>0.01 ;$ IV: Indepent variable, DV: Dependent Variable. 
Figure 2 Hypotheses Testing Results

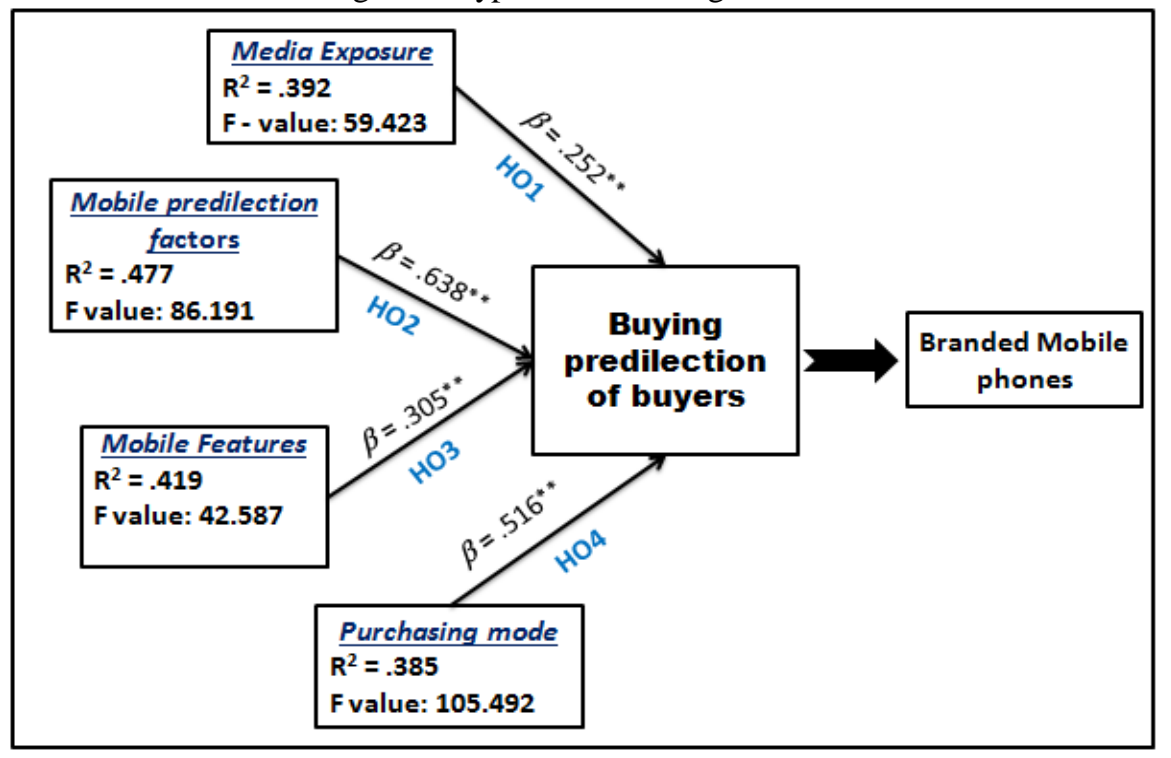

The results shows the causal relatinship between constructs in the analysis, the $\mathrm{R}^{2}$, beta and significance reveale how well the data support to the hypotheses. From table 10 and figure 2 illustrate the results of the multiple rgression; here the results revealed about the impact of independent variables (Media exposure, mobile predilection factors, mobile features and purchasing mode) on dependent variable (purchasing branded mobile phones), Media exposure is positively associated to buyers predilection towards purchasing branded mobile phones $\left(\mathrm{R}^{2}=0.392, \beta=0.252\right.$ and $\left.\mathrm{p}<0.01\right)$, this predictor explain 39.2 percent of the variance on buyers predilection towards purchasing mobile phones; and Mobile predilection factors which are impact on buyers purchasing mode towards mobile phones are significantly related to buyers buying mode $\left(\mathrm{R}^{2}=0.477, \beta=0.638\right.$ and $\left.\mathrm{p}<0.01\right)$ and 47.7 percent of variance caused by the predictors on the criterion varible; next, Moible features are positevely relate to buyers purchasing branded mobile handsets $\left(\mathrm{R}^{2}=0.419, \beta\right.$ $=0.305$ and $\mathrm{p}<0.01), 41.9 \%$ variance caused by predictors in the dependent variables; Similarly, online and offline purchasing mode are positevly relate to buyers purchsing with repsect to branded mobile handsets $\left(R^{2}=0.385, \beta\right.$ $=0.516$ and $\mathrm{p}<0.01$ ). These predictors explain 38.5 percent of variance in the purchaseing mode of buyers; These predictors are statistical significant on the buyers predilction towards purchasing mobile phones. Hence, these findings support $\mathrm{HO} 1, \mathrm{HO} 2, \mathrm{HO} 3$ and $\mathrm{HO} 4$ of this research study.

\section{CONCLUSION, IMPLICATION AND LIMITATION}

The study was investigate the buying predilection of buyers while they are acquiring the chosen mobile phone. The study focused on four independent variables i.e. media exposure, media predilection factors, media features and purchase mode towards buying mobile phones. Based on the results, majority of the buyers buying Samsung mobile phone; buyers spent money for buying handset $15 \mathrm{k}-20 \mathrm{k}$ and they were change their mobile handset within 1-2 years gap.it can be concluded that these four indepedent variable has significant impact on the buying predilection of buyers. As far pearson correlation results, each variable of mobile predilection factors like Brand, price and features are the dominant factors impact the buying predilection of the buyers; followed by mobile handsets features like processsor power, Most of the clients are consider features like compatibility and camera while purchasing mobile handsets; but all mobile features are not having similar influence on predilection clients. The reserachers study conclude that variables like brand name, price, processor power, camera, style and design has more impact on the buying predilection of buyers and most of the buyers prefers offline mobile purchase mode. The research can be useful for the mobile marketrs, becuase of increment in rivalry promts decline in deals for mobile handsets as piece of the overall industry is right now apportioned among the more merchants. The investigation of buying predilection of buyers is critical for marketrs towards branded mobile phones. So the mobile marketrs need to think about the different cell phone features and predilection factors that impact the buyers buying predilection towards branded cell phones to confront this challenge. This investigation could be helpful to mobile marketers for comprehend which triggers a customers intention to buying mobile handsets an they should carefully re think strategies while delivering, promoting circulating new mobile phones spotlight on brand/product positioning, personality, design and differentiation. Buyers pulled in towards new innovative technology, if manufacture use best technology buyers will able to move one mobile handset to another one. Comapnies need to propulsioni lookup studies in imtation of help discover and pick out which instant revolutionary purposes to gather according to their items. which feature coordinates conformity with the present day patterns then buyers needs, then which would keep thrify for the mobile handsets tread. Distinctive wireless organizations are improving the brand or trademark; they additionally need to accept about cost advancement, or lives ought to resemble propagation all things considered. It endorses such an attention more on the advancement of qualities than real PDAs or invest more energy improving its hardware as per lower cost that ought to be attainable using esteem lessening measures; mobile marketers need to think on media exposure, because its plays very significance role in 
terms of creating awareness and building brand image in the target buyers mind. This implies that people's awareness with Brand image is likely to lead people to buy a product. Some limitations of this research study should to be addressed. The study will be done to comprehend the buying predilection of buyers towards branded mobile phones and buyers predilection in the entire mobile sector cant be estimated.The sample chose may not speak to the entire population. Subsequently, the confinement of speculation will be there.

\section{REFERENCES}

1. J. Marumba (2013). "A Pragmatic Assesment of the Determinants of Consumer Brand Prefernce in the Mobile Telecommunication Services Market in Masvingo Urban" Zimbabwe. Management and Administrative Science Review, 2(2), 144-155.

2. K. G. Singh(2012). "Customer Preferences and Satisfaction towards Mobile Phone- The Case of Selected District of Punjab". Asian Journal of Research Marketing, 1(4), 16-31.

3. Kumar Sandeep and Chaubey DS (2015). Customers Preferences of Product Attribute of Mobile Phone Handsets: A Descriptive Study. International Journal of Emerging Research in Management \&Technology, 4(7), 246-250.

4. Ling W, Hwang and Salvendy G (2007). Diversified users' satisfaction with advanced mobile phone features. Universal Access in the Information Society, 5(2), 239-249.

5. Luca Petruzzellis Dipartimento di Studi Aziendali e Giusprivatistici, Universita` degli Studi di Bari, Bari, Italy,2008.

6. M Chowdhury and M. T. Rahman(2013)."Consumer Attitude Towards the Cell Phone; A Study on Young Generations of Chittagong Metropolitan city, Bangladesh", Asian Business Review, 3(5), 16-20.

7. M. Sata (2013). "Factors Affecting Consumer Buying Behaviour of Mobile Phone", Mediterranean Journal of Social Science, 4 (12), 103-112.

8. Macro Analysis \& Consumer Research Organisation (2004). Study of Mobile Phone Usage Among the Teenagers And Youth In Mumbai. Reterived from https://www.itu.int/osg/spu/ni/futuremobile/socialaspects/IndiaMacroM obileYouthStudy04.pdf.

9. P Gopal, Anjali and Aakanksha (2013).“Mobile Marketing Research: A Study of Brand Prefrence by VIT Student's", International Journal of Advanced Research in Computer Science and Software Engineering, 11, 1620-1623.

10. Parveen Kumari, Satinder Kumar (2016). Consumer Brand Preference towards Mobile Phone: Effect of Mobile Phone Attributes on Purchase Decision. IOSR Journal of Business and Management (IOSR-JBM), Special Issue - AETM'16.

11. R. Rijial (2013). Brand preference on Mobile Purchase among the Students of Roskilde University, Bechelor of Business studies Project report, Roskilde University.

12. S. Malviya, M. S. Saluja and A. S. Thakur (2013). A Study of the Factors Influencing Consumer's Purchase Decision towards Smartphones in Indore. International Journal of Advanced Research in Computer Science and Management Studies, 1(6), 2013, 14-21.

13. S. Mokhlis and A. Y. Yakoop (2012).Consumer Choice criteria in Mobile Phone selection: An investigation of Malaysian University student, International review of Social Science \& Humanities, 2(2), 2012, 203-212.

14. Sama, R. (2019). Impact of Media Advertisements on Consumer Behaviour. Journal of Creative Communications, 14(1), 54-68.

15. Savitha Nair, Nivea Nelson N and Karthika R (2016). Consumer preference towards mobile phones: An empirical analysis. International Journal of Applied Research 2016; 2(12): 343-347 .

16. Shanka, Mesay Sata. (2013). Factors Affecting Consumer Buying Behavior of Mobile Phone Devices. Mediterranean Journal of Social Sciences. 4. 103 - 112. 10.5901/mjss.2013.v4n12p103. 